\title{
The migrations of Finnish Bean Geese Anser fabalis in 1978-2011
}

\author{
Flyttning hos finska sädgäss Anser fabalis 1978-2011
}

LEIF NILSSON

\begin{abstract}
Bean Geese Anser fabalis have been neck-banded extensively in the breeding areas in northern Finland during two periods: 1978-1994 and 2002-2009. The observations of these geese showed marked differences in timing of migration and location of wintering and staging areas between the two periods. The Bean Geese stayed further to the north in south Sweden during the autumn in the latter period and arrived later to wintering areas in southernmost Sweden. Moreover they did not go to the Netherlands and western Germany during cold winters in

the second as they did in the first period. Spring migration started earlier in the second period. Most patterns revealed by the Finnish neck-banded geese were the same as those shown by the Bean Geese in general as observed by the national goose counts in southern Sweden.

Leif Nilsson, Department of Biology, Biodiversity, Ecology Building, S- 22362 Lund, Sweden.

Leif.nilsson@biol.lu.se
\end{abstract}

Received 11 October 2011, Accepted 29 October 2011, Editor: S. Svensson

\section{Introduction}

During the 1970s, there was much concern for the situation of the breeding Bean Goose populations of northernmost Fennoscandia, and the Nordic Collegium for Wildlife Research (NKV) established a special working group in 1975 with the task to run a Nordic Bean Goose Project (Nilsson \& Fog 1984). The studies undertaken within this program included several different aspects of the ecology of Bean Geese such as breeding ecology (Pirkola \& Kalinainen 1984), non-breeding ecology and censuses (Nilsson \& Persson 1984), and migration studies (Lampio 1984, Nilsson 1984, Tveit 1984). The project also led to the start of regular goose monitoring in Sweden (Nilsson 2000).

The studies of Bean Goose migration was based on individual neck-banding of geese in different areas and searches for the marked geese on the staging and wintering areas. After the termination of the NKV project this neck-banding project continued as a joint Finnish-Swedish project (Nilsson \& Pirkola 1986, 1991).

Whereas most other goose populations have shown positive development, this has not been the case for the Taiga Bean Goose Anser f. fabalis which is breeding in northern Fennoscandia and further to the east in Russia (Nilsson et. al. 1999, Fox et al. 2010). During the 2000s there was a renewed interest in the Bean Geese of northern Fennoscandia. In Sweden, discussions concerning Bean Goose management started with the debate related to a major railroad through one of the most important spring staging areas at Umeå in northern Sweden (Botniabanan). At the same time, a national Bean Goose Project was started in Finland. The studies in both countries included neck-banding programs.

The regular goose counts in Sweden have shown marked changes in the distribution of staging Bean Geese in southern Sweden during early autumn, from Scania to sites up to about $500 \mathrm{~km}$ to the north, such as Tåkern and Kvismaren (Nilsson $2000,2008)$. In the present contribution I will analyze the observations of neck-banded Finnish Bean Geese and compare the migration patterns for the two different marking periods that are characterized by these different staging patterns. This paper does not analyze the migratory movements of Bean Geese within Finland with the exception that observations in April in Finland are included for comparison with movements along the Swedish coast of the Bothnian Sea.

Neck-band observations were to a large extent 


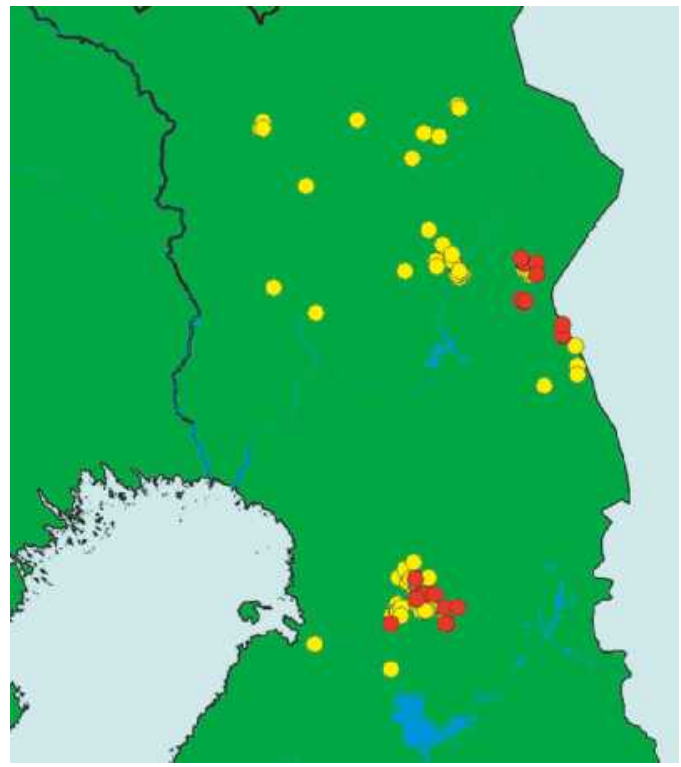

Figure 1. Marking places for Finnish neck-banded Bean Geese Anser fabalis. Yellow = marked before 2000, red $=$ marked after 2000 .

Märkplatser för finska halsbandsmärkta sädgäss Anser fabalis. Gul = märkta före 2000, röd = märkta efter 2000.

obtained directly from the observers. In addition to this, the Finnish Bird Ringing Office has put all records of marked and observed neck-banded Bean Geese at my disposal.

\section{Material and methods}

Neck-banding of Bean Geese in the Nordic countries started in south Sweden in 1976 and in Finland in 1978 as a part of the Nordic Bean Goose Project (Nilsson1984). Bean Geese were captured in Finland both on spring staging areas, moulting areas and breeding areas. On staging areas cannon nets were used, whereas moulting and flightless families were captured on the breeding grounds using different methods described in Pirkola \& Kalinainen (1984).

During the Nordic Bean Goose Project, orange neckbands with a three digit code were used in Finland, Norway and Sweden. The same type of neckbands but of a more red colour was used in the second period of catching in Finland, the neckbands having either two-digit or three-digit codes.

During 1978-1994, 710 Bean Geese were neckbanded in Finland. The activity was resumed in

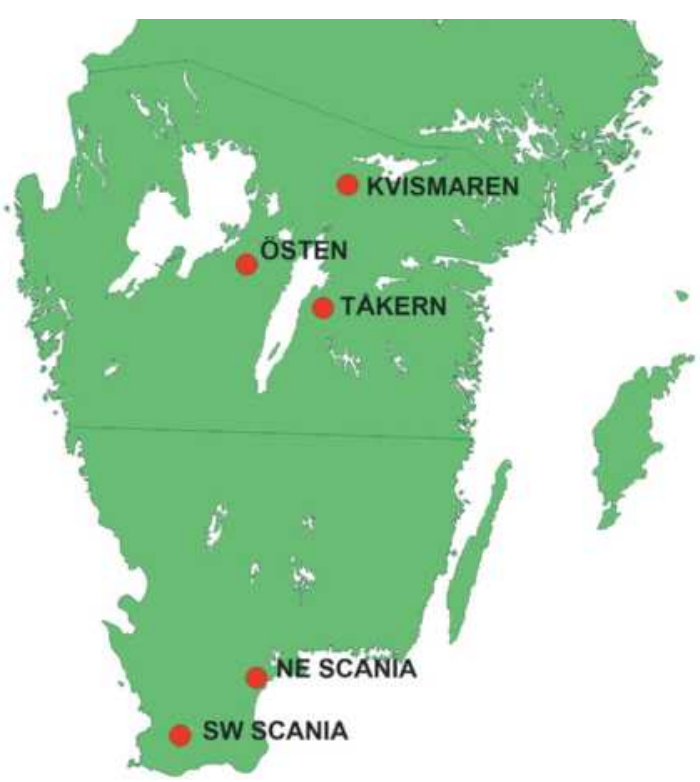

Figure 2. Important staging and wintering areas for Bean Geese Anser fabalis in south Sweden.

Viktiga rast- och övervintringslokaler för sädgäss Anser fabalis $i$ södra Sverige.

2002, and through 2009 another 173 Bean Geese were neck-banded. In the analysis below the number of individuals checked in the latter period is somewhat higher as some birds from the markings in the 1990s still survived. The geographical positions of the marking areas are shown in Figure 1.

The main staging areas in south Sweden mentioned in the text are shown in Figure 2. For further details of the distribution of staging and wintering Bean Geese in Sweden see Nilsson (2000).

\section{Results}

During the first period, 1978-1994, a total of 5400 observations of Bean Geese that had been neckbanded in Finland were reported, whereas 2010 observations were reported in the second period 2002-2009. However, these totals include observations within Finland, which are not analyzed here. From outside Finland, 3038 neck-band readings were available from the first and 1108 from the second period.

Finnish Bean Geese arrive into Sweden in September-October, with the majority in October. 
They arrive within a quite narrow zone at the coast of the province of Uppland after a passage over the Åland archipelago between Finland and Sweden. In general, the neck-banded Bean Geese from Finland were found in the eastern part of mainland Sweden from the arrival area in Uppland south to the province of Scania (Figure 3). A number of observations were also obtained from Denmark, Germany and the Netherlands, mainly from the winter (Figure 4). Only small numbers were found in the western part of south Sweden.

Some differences in distribution of neck-band readings from the two time periods were found, although the general picture was more or less the same. Within Sweden, one striking difference between the two periods is the much lower number of neck-bands reported from Tåkern in the latter period compared to the first period. There is also a tendency of fewer readings in southwestern Scania during the second period, but this difference is more apparent when each month is analyzed separately.

During the first period several reports of Finnish neckbands were obtained from the Netherlands with a few observations also from Schleswig-Holstein in Germany and Jutland in Denmark. Observations from these areas are totally lacking for the second period. Finnish Bean Geese were still found to a similar extent in the Danish Isles and also in the northern parts of eastern Germany.

In September, neck-band observations of Finnish Bean Geese were mostly from the province of Uppland and the Kvismaren area, but a few observations were also noted at Lake Tåkern. In the first period there were also three records from further south, including one from the German/Polish border.

October is the peak month for staging Bean Geese in Sweden (Nilsson 2000, 2008). The majority of the neck-band readings were reported from Kvismaren and Tåkern with smaller numbers from the other sites. During the first period, Kvismaren and Tåkern were both very important areas with more than 100 neck-band readings each, whereas Tåkern had lost much of its importance during the second period. In the first period, southwestern Scania was also much used by the Finnish Bean Geese with several neck-bands reported, but only

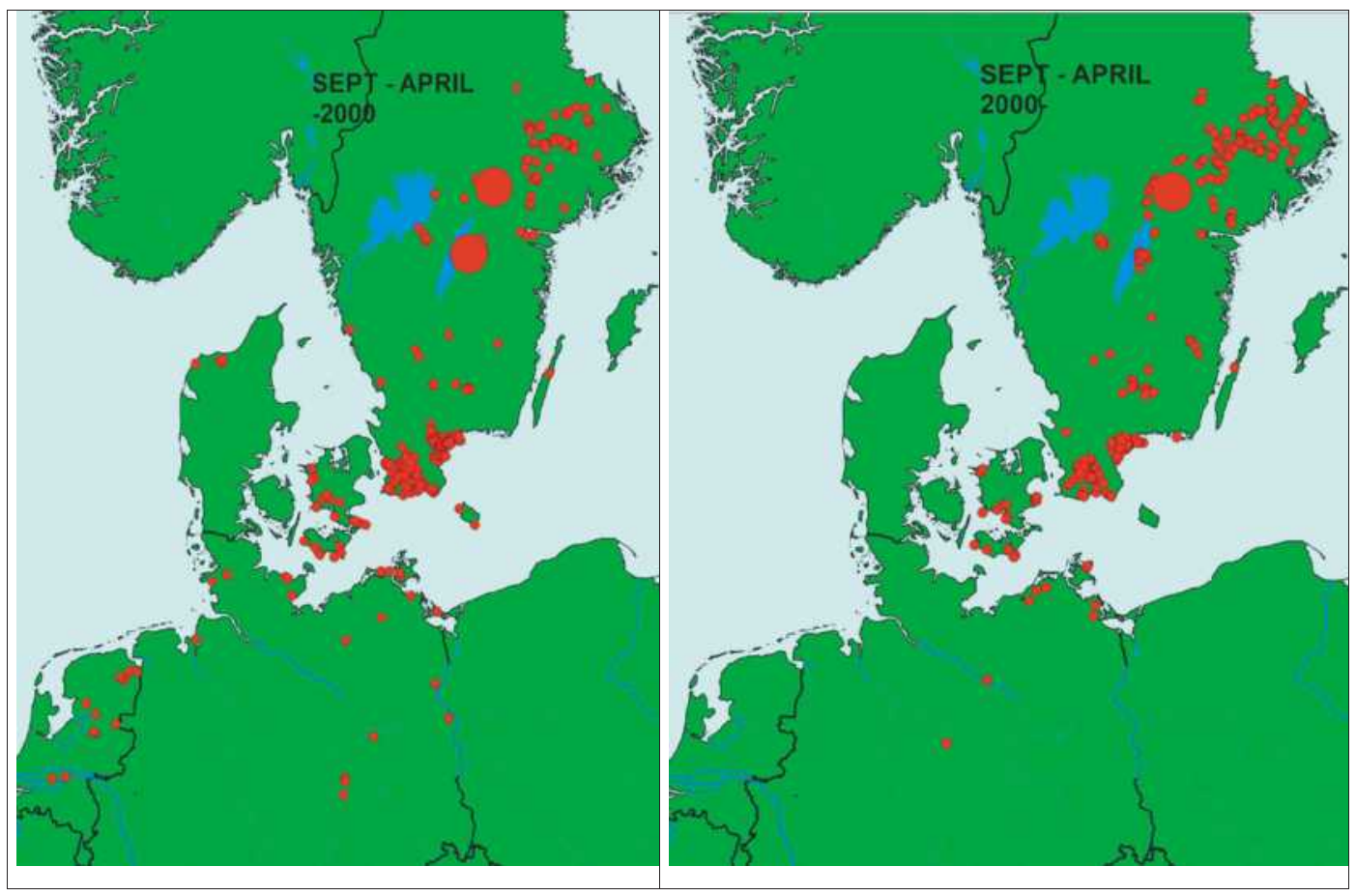

Figure 3. Observations of neck-banded Finnish Bean Geese Anser fabalis from September-April before 2000 (left) and after 2000 (right).

Observationer av halsbandsmärkta finska sädgäss Anser fabalis från september-april före 2000 (vänster) och efter 2000 (höger). 

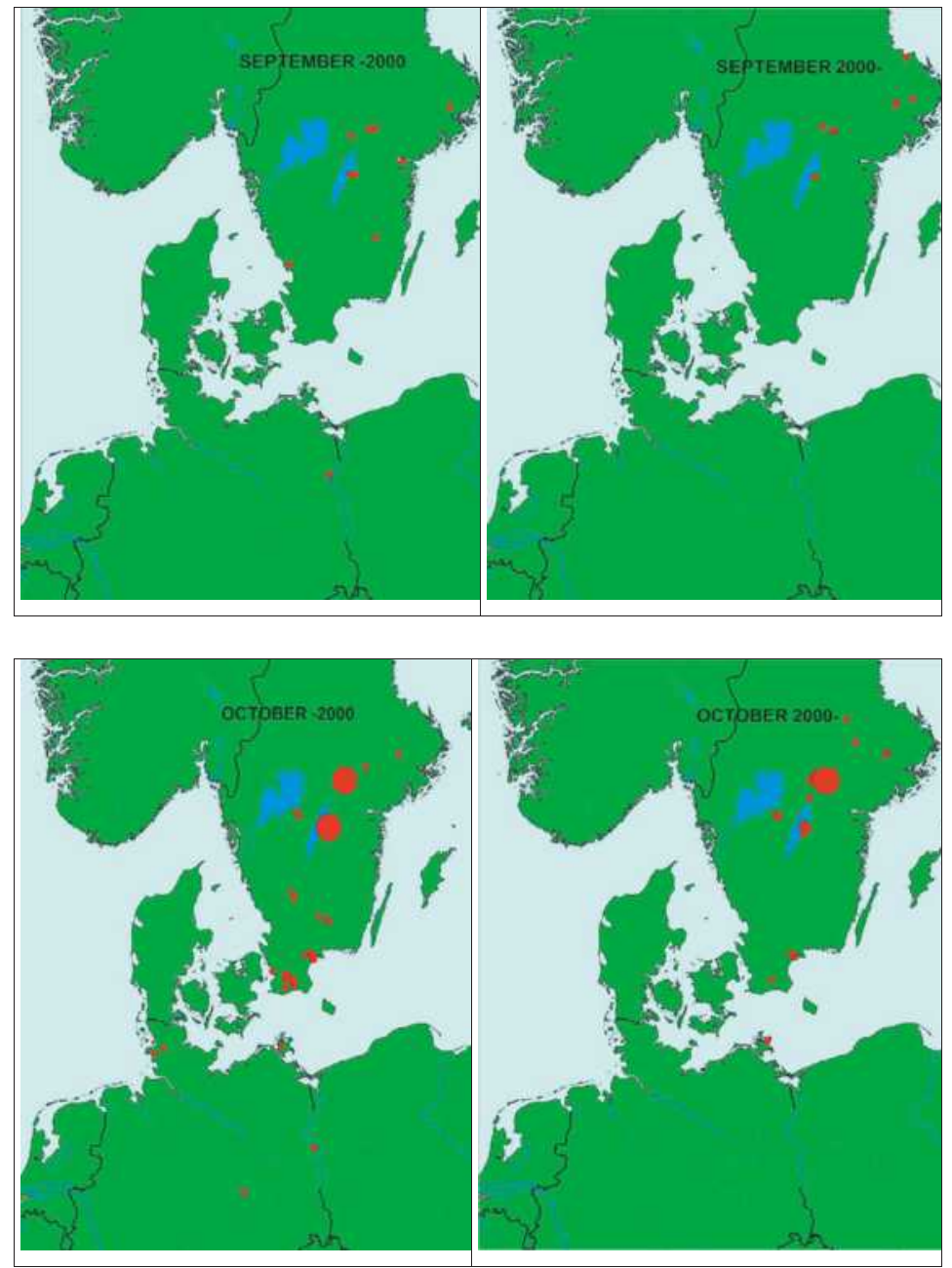

Figure 4. Observations of neckbanded Finnish Bean Geese Anser fabalis from different months during September-April before 2000 (left) and after 2000 (right). Note that observations from Finland are included for April to allow comparisons with the Swedish coast of the Bothnian Sea. Observationer av halsbandsmärkta finska sädgäss Anser fabalis från olika månader under septemberapril före 2000 (vänster) och efter 2000 (höger). Notera att finska observationer visas på kartan för april för att möjliggöra jämförelser med den svenska sidan av Bottenhavet. one observation was reported here in October during the second period.

November and December are transition months between the autumn staging period and the winter period, and the distribution of the Bean Geese is much influenced by the weather. With early frost the geese leave the northern staging areas and more geese are found in Scania. Still there were some marked geese remaining at the northern sites in November, in mild winters also in December. These northern observations in November and December were relatively more frequent than in Scania during the second period.

January and February are more typical winter months. Most neckband readings were reported from Scania, both from the southwestern and the northeastern part. Comparing these two parts for the winter months do not reveal any marked differences in the total picture. Some neckband readings were also obtained from further north in Sweden, mostly from mild winters.

March is normally a spring migration period for the Bean Geese in south Sweden with observations all the way from Scania to the province of Uppland, where the majority of the Bean Geese from Finland leave Sweden. A comparison of the reported readings in the two time periods clearly shows that the migration north was earlier in the second period with relatively much fewer marked Bean Geese staying in Scania in March.

In April, spring migration was apparent even further north in the country and many neck-banded 

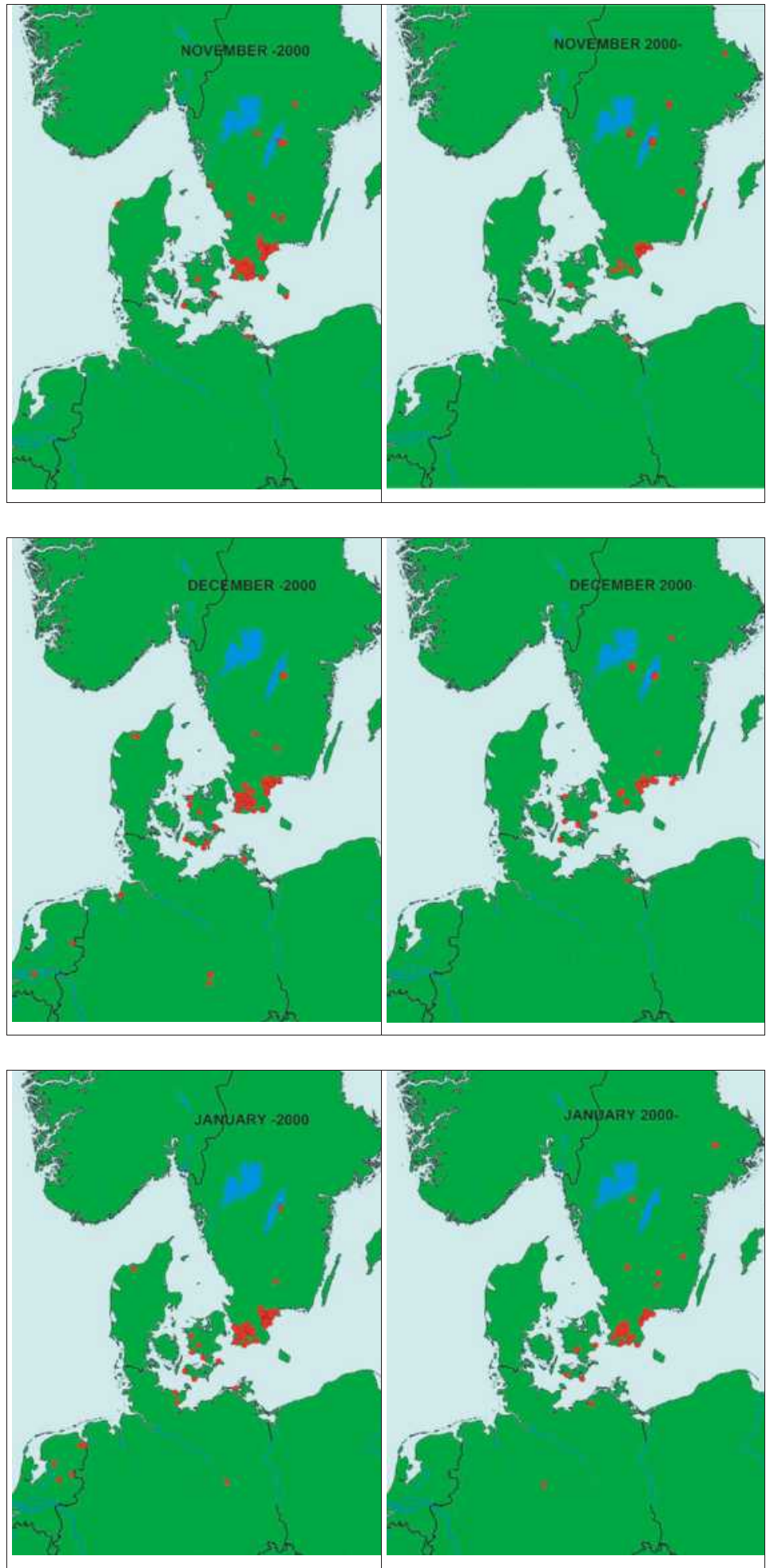

Figure 4. continued fortsättning 

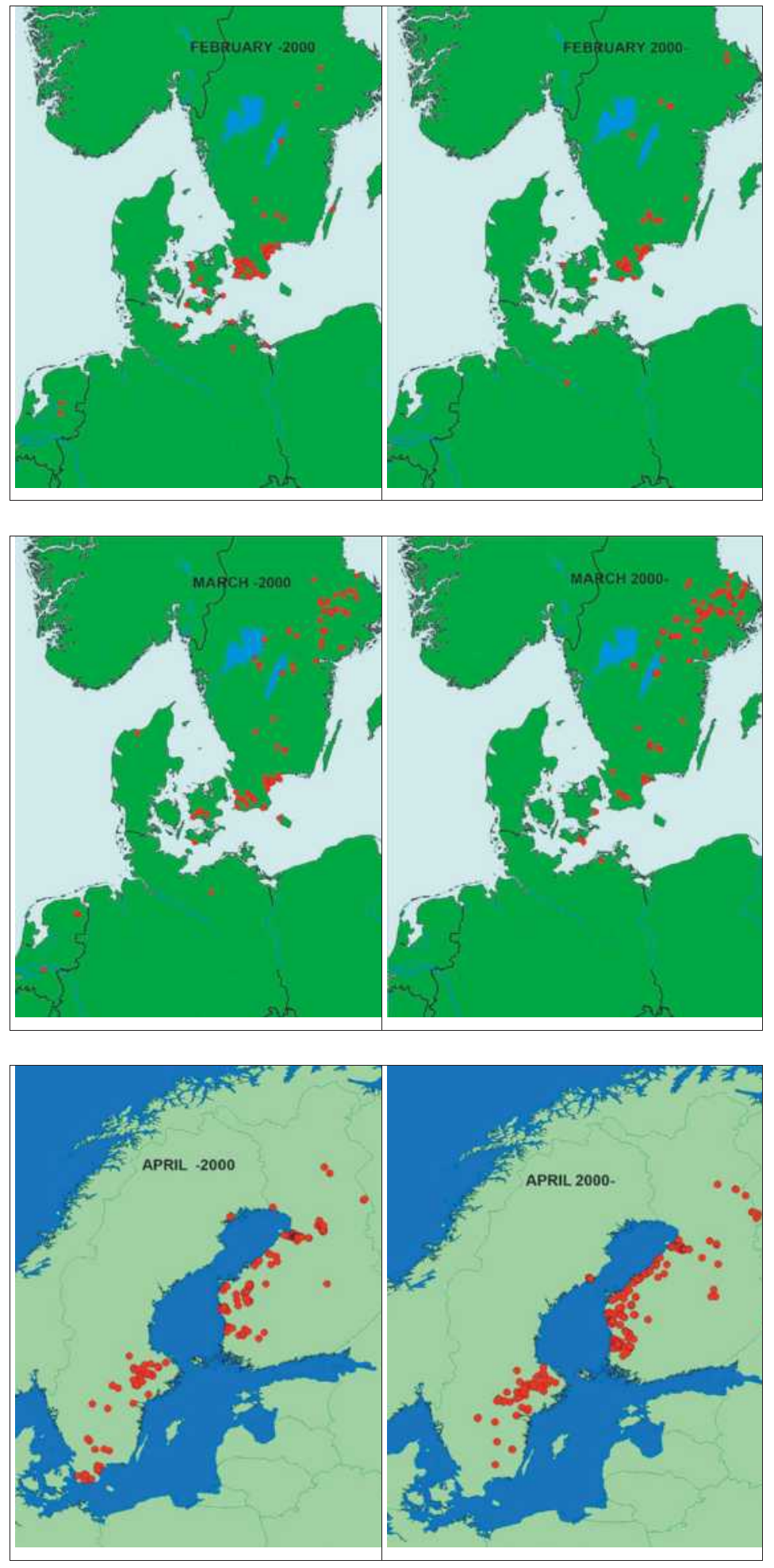

Figure 4. continued fortsättning 


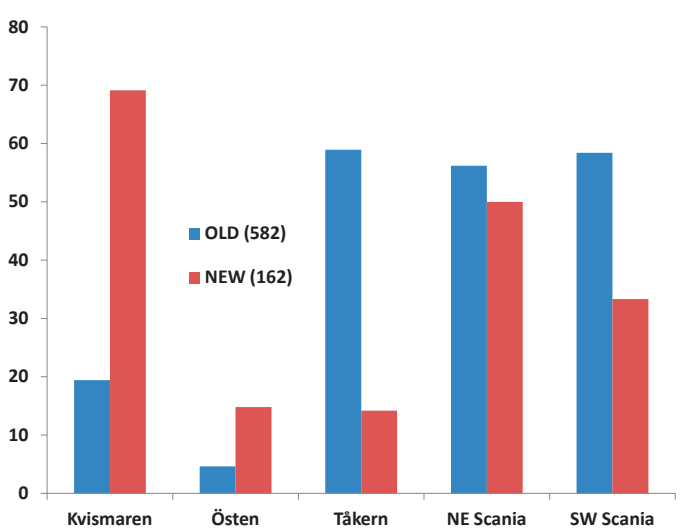

Figure 5. Percentage of all Finnish neck-banded Bean Geese Anser fabalis which have been recorded at the main staging and wintering areas in south Sweden. In all, 582 individuals are included in the sample marked before 2000 whereas the sample marked after 2000 include 162 individuals.

Andelen av samtliga finska halsmärkta sädgäss Anser fabalis som har setts på de viktigaste rast/övervintringsområdena $i$ södra Sverige. Sammanlagt ingår 582 individer som märkts före 2000 och setts $i$ Sverige, medan motsvarande antal för de som märkts efter 2000 är 162.
Bean Geese had reached Finland. During the first period several marked Bean Geese of Finnish origin were still left in Scania, whereas all of them had left the province during the second period. Observations from the province of Småland were also much fewer during the second compared to the first period. The maps for April show very clearly that the Finnish Bean Geese wintering in Sweden fly over the Baltic Sea via Alland to southwest Finland and then migrates north in the western part of Finland. Only six observations were obtained from the Swedish side of the Bothnian Bay, two at Luleå during the first period and four in the Ume River delta during the second period.

As already clear from the comparison of the two sets of maps from the first and second study period, there were marked changes in the distribution of the Bean Geese between the two periods and also between the neck-band readings during the two periods. In the first period, more than 50\% of all marked Bean Geese seen in Sweden were also seen at least once at the three major staging/ wintering sites Tåkern and the two parts of Scania (Figure 5). Relatively small proportions of the
Figure 6. Detailed map of Scania, the southernmost province of Sweden, with observations of neck-banded Bean Geese Anser fabalis marked before 2000 (blue) and after 2000 (red).

Detaljkarta over Skåne med observationer av halsmärkta finska sädgäss Anser fabalis märkta före 2000 (blå) resp. märkta efter 2000 (röda).

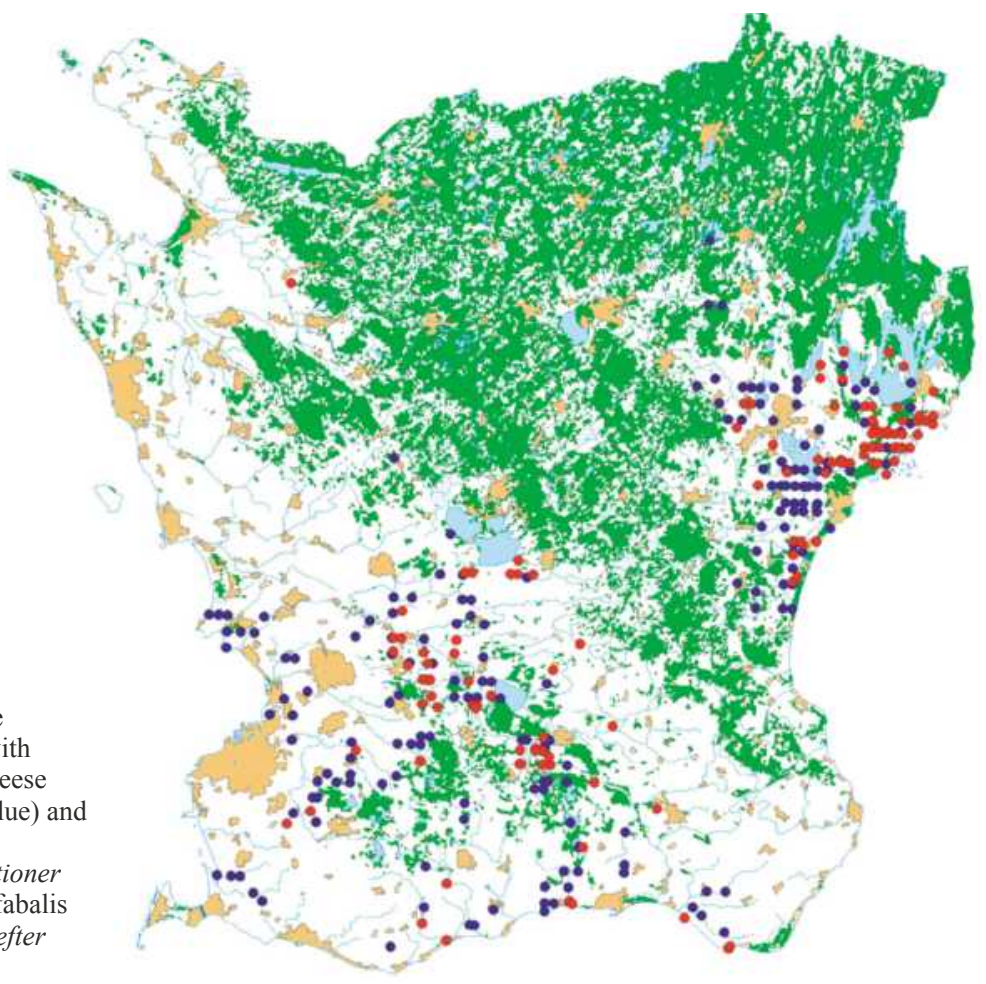


marked geese were seen at Kvismaren and Östen in those years.

In the second period, the picture was totally different with close to $70 \%$ of all neck-banded Finnish Bean Geese seen in Sweden reported from Kvismaren at least once. Several of them were also seen at other sites. The proportion of marked geese seen in Scania was lower, but still about $50 \%$ were noted in northeast Scania, i. e. more or less the same percentage as in the first period, but the proportion reported from SW Scania was much lower in the second period. At Tåkern, only about $15 \%$ of the neck-bands from Finland were seen during the second period compared to nearly $60 \%$ in the first period. The shift in importance for staging geese in the autumn from Tåkern to Kvismaren was very apparent.

A detailed mapping of the neck-band readings from Scania show marked differences between the two time periods, especially in the southwestern part of the province (Figure 6). During the first period, important numbers of geese with many neckbands readings were found at the coastal sites especially during cold periods. In the second period most of the Bean Geese remained inland, and for the lake area in southwestern Scania there were no differences between the two periods. In the northeast there were more observations close to the coast during the second period, whereas most observations of neck-banded Bean Geese from the first period were reported from more inland areas.

\section{Discussion}

In an earlier analysis of the migration pattern of Finnish neck-banded Bean Geese, Nilsson \& Pirkola (1991) separated three main groups (see also Nilsson 1984, Nilsson \& Pirkola 1986): (A) a group migrating to southern Sweden (and Denmark) from breeding areas in northern Sweden (and Norway), (B) an easterly group migrating into Sweden over Finland, probably coming from areas in Russia, and (C) a group coming from the Finnish breeding areas, maybe also parts of western Russia. The reason to separate the two groups $\mathrm{B}$ and $\mathrm{C}$ was mainly a marked influx of Taiga Bean Geese into Germany during autumn without producing any larger numbers of neck-band readings, indicating that they came from areas further to the east where no neck-banding was undertaken. If this early influx had come from Finland many more readings should have been reported.

Group A geese (mainly Swedish) seem to have very few connections with group $\mathrm{C}$ geese (mainly Finnish), with only six observations of the latter on the Swedish side. Group A probably consists of two subgroups, one migrating south to wintering areas in southernmost Sweden and another, probably from the southern part of Swedish Lapland, migrating to Britain via Denmark (Parslow-Otsu 1991). Group A and group $C$ geese mix with each other in the winter-quarters as shown by neckbanding in Scania (Nilsson 1984).

The general picture of the migration of Bean Geese through Sweden from the Finnish marking areas is the same in the two time periods that are compared, with the exception that the geese did not reach western Germany and the Netherlands in the second period. During the first period they reached Scania and stayed there in normal winters, but moved further on and reached as far as the Netherland in winters with cold spells. In the latter period the Bean Geese from the Finnish marking areas still had Scania as a main winter area, but they did not reach further to the southwest than the Danish Isles.

The marked differences in neck-band reports between the two time periods were also reflected in the standard autumn counts of staging Bean Geese (Nilsson 2008). There was a shift in the migration schedule with the geese staying longer in more northerly parts of south Sweden and a much later arrival in Scania in the second period. This shortstopping was probably mostly related to changes in the agriculture with improved feeding conditions in the areas north of Scania, partly related to a shift to autumn-sown cereals. The standard autumn counts also showed a shift in the importance of different staging areas (Nilsson 2008). When the counts started in the late 1970s, very few geese were staging north of Scania in October, whereas hardly any geese had reached Scania in that month during the 2000s. Tåkern was taking over the dominance for a number of years, but then the picture changed again and Kvismaren grew to become the most important autumn area.

The shift of spring migration to earlier dates was about the same for the Swedish and Finnish populations. It is assumed (Drent et al. 2006, Nilsson 2006, Tombre et al. 2008) that this shift is associated with an ongoing amelioration of spring climate, making grazing habitats available at earlier dates along the whole migration route and also in the breeding areas.

\section{References}

Drent, R.H., Fox, A.D. \& Stahl, J. 2006. Traveling to breed. Journal of Ornithology 147: 122-134. 
Fox, A. D. , Ebbinge, B.S., Mitchell, C., Heinicke, T., Aaarvak, T., Colhoun, K., Clausen, O., Dereliev, S., Farago, S., Koffijberg, K., Kruckenberg, H., Loonen, M.J.J., Madsen, J., Mooij, J., Musil, P., Nilsson, L., Pihl, S. \& van der Jeugd, H. 2010. Current estimates of goose population sizes in western Europe, a gap analysis and an assessment of trends. Ornis Svecica 20: 115-127.

Lampio, T. 1984. On the spring migration of the Bean Goose, Anser fabalis, in Finland. Swedish Wildlife Research 13: $59-72$.

Nilsson, L. 1984. Migrations of Fennoscandian Bean Geese, Anser fabalis. Swedish Wildlife Research 13: 83-106.

Nilsson, L. 2000. Changes in numbers and distribution of staging and wintering goose populations in Sweden, 1977/78-1998/99. Ornis Svecica 10: 33-49.

Nilsson, L. 2006. Changes in migration patterns and wintering areas of South Swedish graylag geese Anser anser. Pp. 514-516 in Waterbirds around the world (Boere, G. C., Galbraith, C. A. \& Stroud, D. A., eds.) The Stationary Office, Edinburgh, UK.

Nilsson, L. 2008. Recent changes in numbers and distribution of the Taiga Bean Goose Anser fabalis fabalis in south Sweden during 1977-2005. Vogelwelt 129: 263-267.

Nilsson, L. \& Fog, M. (eds.) 1984. Studies on Fenniscandian populations of Bean Goose (Anser fabalis), Greylag Goose (Anser anser) and White-fronted Goose (Anser erythropus). Swedish Wildlife Research 13: 1-221.

Nilsson, L., van den Bergh,L. \& Madsen, J. 1999. Taiga Bean Goose Anser fabalis fabalis. Pp. 20-36 in Goose populations of the Western Palearctic. A review of status and distribution. (Madsen, J., Cracknell, G. \& Fox, A.D., eds.). Wetlands International, Wageningen.

Nilsson, L. \& Persson, H. 1984. Non-breeding distribution, numbers and ecology of Bean Goose, Anser fabalis, in Sweden. Swedish Wildlife Research 13: 107-170.

Nilsson, L. \& Pirkola, M.K. 1986. The migration pattern of Bean Geese Anser fabalis in the Baltic area. Vår Fågelvärld, Suppl. 11: 147-153.

Nilsson, L. \& Pirkola, M.K. 1991. Migration pattern of Finnish Bean Geese Anser fabalis. Ornis Svecica 1: 69-80.

Parslow-Otsu, M. 1991. Bean Geese in the Yare Valley, Norfolk. British Birds 84: 161-170.

Pirkola, M.K. \& Kalinainen, P. 1984.The status, habitats and productivity of breeding populations of Bean Goose, Anser fabalis fabalis, in Finland. Swedish Wildlife Research 13: 9-48.

Tombre, I.M., Högda, K.A., Madsen, J., Griffin, L.R., Kuijken, E., Shimmings, P., Rees, E. \& Verscheure, C. 2008. The onset of spring and timing of migration in two arctic nesting goose populations: the pink-footed goose Anser brachyrhynchus and the barnacle goose Branta leucopsis. Journal of Avian Biology 39: 691-703.

Tveit, G. 1984. Autumn migration, wintering areas and survival of Bean Geese, Anser fabalis, marked on the moulting grounds in Finnmark, North Norway. Swedish Wildlife Research 13: 59-72.

\section{Sammanfattning}

Under 1970-talet genomfördes ett nordiskt sädgåsprojekt på uppdrag av Nordisk Kollegium för Viltforskning. Inom ramen för detta projekt studerades olika aspekter på sädgåsens ekologi, bl.a. dess flyttningsvanor. Flyttningsstudierna baserades på halsbandsmärkning av sädgäss på vinterområden i Skåne, häckningsplatser i Finland samt ruggningslokaler i Norge och Finland. Projektet fortsatte sedan som ett finskt - svenskt projekt som dock avslutades 1994.

Under 2000-talet uppkom ett förnyat intresse för sädgässen i Sverige och Finland och nya märkprojekt startades i båda länderna. I denna uppsats jämför jag flyttningsmönstret för de sädgäss som märktes i Finland under den första perioden (19781994) med dem som märktes under den andra perioden 2002-2009. Undersökningen omfattar inte rörelserna av sädgäss i Finland med undantag för vårflyttningen för att möjliggöra jämförelser med förhållandena på den svenska sidan.

Sädgäss har fångats på olika lokaler i Finland (Figur 1) med hjälp av kanonnät på rastplatser och genom att driva ruggande gäss och ungar in i nät.

Under 1978-1994 märktes totalt 710 sädgäss med halsringar i Finland, medan 173 sädgäss märktes under perioden 2002-2009.

\section{Resultat}

Under den första perioden med halsbandsmärkning rapporterades totalt 5400 observationer av de halsmärkta gässen, medan motsvarande antal var 2010 för den senare perioden fram till våren 2011. Totalt har jag haft tillgång till 3038 rapporterade avläsningar utanför Finland från den första perioden och 1108 för den senare perioden.

De finska sädgässen anlände till Sverige under september-oktober, med majoriteten under den senare månaden. Huvudankomsten skedde över ett ganska begränsat område längs Upplandskusten. I huvudsak observerades de finska sädgässen i östra Sverige i ett bälte från ankomstområdet i Uppland ner till övervintringsområdena i Skåne (Figur 3). Ett antal observationer rapporterades också från Danmark, Tyskland och Nederländerna, huvudsakligen från vintern (Figur 4).

Om fördelningen av observationer från de båda tidsperioderna med halsbandsmärkning jämförs framträder huvudmönstret som det beskrivits ovan $i$ båda tidsperioderna, men det föreligger en hel del skillnaderna, särskilt om man jämför observationernas fördelning på olika månader i de båda serierna. Skillnaderna är tydliga under vintern. Den första perioden erhölls flera rapporter från Nederländerna samt västra delen av Tyskland samt Jylland i Danmark. Sådana observationer saknas helt från den senare perioden. Däremot frekventerade 
sädgässen de östra delarna av Danmark under båda perioderna.

Inom Sverige förelåg också en hel del skillnader mellan perioderna. I samlingskartan framgår tydligt att Tåkern var av mindre betydelse som rastplats under den senare perioden jämfört med den första perioden. På motsvarande sätt är antalet observationer från sydvästra Skåne inte lika framträdande under den senare perioden.

Jämför man fördelningen mellan de båda tidsperioderna för de olika månaderna är skillnaderna mellan perioderna mer tydliga. I oktober, som är huvudmånad för sädgässen i Sverige, kan man tydligt se förskjutningen från Skåne och Tåkern som viktiga lokaler mot Kvismaren. Så finns endast en rapport från SV Skåne från den senare perioden i oktober jämfört med flera från första perioden. Under november-december kan man också se en tydlig skillnad mellan de båda skånska områdena, med fler sädgäss i nordöstra Skåne jämfört med sydvästra Skåne.

Vårflyttningen av sädgäss skedde tidigare under den andra perioden. I mars hade gässen under andra perioden nästan lämnat Skåne, medan fortfarande betydande antal sädgäss fanns kvar här under den första perioden. Bilden för april var ganska likartad mellan de båda perioderna, merparten av de finska gässen flyttade över Ålands hav mot sydvästra Finland, medan endast mycket få finskmärkta sädgäss observerades på den svenska sidan av Bottenhavet.

Som framgår av kartorna har det skett betydande omfördelningar av de finska sädgässens uppträdande i Sverige mellan de båda undersökningsperioderna. Detta framgår särskilt tydligt av Figur 5. Under den första perioden sågs över $50 \%$ av samtliga individer kontrollerade i Sverige åtminstone vid en av de tre områdena Tåkern, SV och NE Skåne, medan endast en mindre andel sågs vid Kvismaren. Under den senare perioden var Kvismaren den viktigaste lokalen i Sverige, där nära $70 \%$ av alla avlästa gäss från Finland observerats vid åtminstone ett tillfälle, medan Tåkern förlorat markant i betydelse.
I Skåne noterades också betydande skillnader i gässens uppträdande mellan de båda tidsperioderna, inte bara i skillnaderna mellan de båda delarna i stort utan också på det lokala planet (Figur 6). Speciellt påtagligt är avsaknaden av observationer av märkta gäss från kusterna under den senare perioden jämfört med den första.

\section{Diskussion}

Tidigare analyser av de finska och svenska sädgässens flyttning visade att vi i Sverige kan räkna med tre olika huvudgrupper av sädgäss under flyttningsperioden : A) en grupp sädgäss som flyttar från norra Sverige till södra Sverige och Danmark, B) en östlig grupp sädgäss som flyttar genom Finland och Sverige till vinterområden söder om Östersjön samt en tredje grupp C) som flyttar från finska häckningsområden till övervintringsområden i södra Sverige och (under kallare perioder) till Danmark. Fynden av halsmärkta gäss visar att det inte under någon av perioderna förekommit mer än marginellt utbyte av gäss mellan populationerna $\mathrm{A}$ och C.

I denna undersökning har den tredje gruppens flyttningsvanor under två perioder jämförts och det har kunnat konstateras att gässen i betydande utsträckning ändrat rastvanor i södra Sverige under hösten, vilket också återspeglas i de nationella gåsinventeringarna. Samtidigt konstateras att gässen flyttar ner till sydligaste Sverige senare och inte flyttar lika långt åt sydväst under kallare perioder som tidigare. Sålunda saknades observationer från västar Tyskland och Nederländerna under den senare perioden.

Vårflyttningen konstaterades också vara tidigare under den senare perioden, vilket gäller gäss av både finskt och svenskt ursprung. Detta hänger samman med att vårens snögräns flyttats längre norrut så att betesmarkerna både längs flyttvägen och i häckningsområdet blivit tillgängliga tidigare. 